Rachel Jakhelln

Institutt for larerutdanning og pedagogikk

UiT Norges arktiske universitet

E-post: rachel.jakhelln@uit.no

Kristin Emilie Bjørndal

Institutt for lcererutdanning og pedagogikk

UiT Norges arktiske universitet

\title{
Gerd Stølen
}

Institutt for læererutdanning og pedagogikk

UiT Norges arktiske universitet

\section{Masteroppgaven - relevant for grunnskolelæreren?}

\begin{abstract}
Sammendrag
UiT Norges arktiske universitet har gjennomført en nasjonal pilot i grunnskolelcererutdanning på masternivå, hvor de første studentene fullførte utdanningen og leverte masteroppgave våren 2015. Denne artikkelen fokuserer på hvilken relevans studentene opplever at masteroppgaven har for den fremtidige profesjonsutøvelsen deres. $\AA$ undersøke studentenes oppfatning av masterarbeidet er av betydning, ikke bare fordi masterutdanning blir en nasjonal ordning fra 2017, men også for å utvikle kunnskap om betydningen av forsknings- og utviklingskompetanse for grunnskolelcerere. Studiens empiriske materiale er en intervjuundersøkelse med 22 av de 61 første masterstudentene. Undersøkelsen inngår i en longitudinell studie som vil belyse nyutdannedes profesjonslæring i starten av karrieren, og konkret hvordan lcerere integrerer kunnskapen fra utdanningen med kunnskap og erfaringer de utvikler som ferske lerere. Resultatene fra denne delstudien viser at masterarbeidet har gitt studentene dybdekunnskap og FoU-kompetanse som er av betydning for den videre profesjonsutøvelsen. Studien viser også at det er betydningsfullt at masteroppgaven har forankring i skolens praksis og bidrar til utviklingen som lerer. Av materialet fremgår det også at studentene fremhever selvstendighet og evne til samarbeid, og de er stolte av masterarbeidet sitt. Resultatene er drøftet opp mot begrepene konseptuell og kontekstuell kunnskap (Afdal \& Nerland, 2012; Muller, 2009) og i lys av profesjonsteori. Masterarbeidet synes avgjørende for profesjonsidentiteten, men det vil kreves et systematisk utviklingsarbeid for å kunne gi masterarbeidet kvaliteter som kan støtte opp om studentenes utvikling som profesjonelle larere. For larerutdanningene tilsier dette at FoU-kompetanse må gis oppmerksomhet fra første dag i utdanningen.
\end{abstract}

Nøkkelord: grunnskolelærerutdanning, masteroppgave, nyutdannet læerer, FoU-kunnskap, profesjonell identitet, profesjonsidentitet, konseptuell/kontekstuell kunnskap 


\begin{abstract}
The National Teacher Education Curriculum in Norway will from 2017 be taught at master's level, extending from four to five years. In relation to this, The University of Tromsø, the Arctic University of Norway, in 2010 launched a national pilot program in teacher education: a five year long research-based master's degree, divided into two programs adjusted to the Norwegian educational system: $1^{\text {st }}-7^{\text {th }}$ and $5^{\text {th }}-10^{\text {th }}$ grade, from which the first students graduated in the spring of 2015. This article aims to examine the importance the master's thesis holds for teacher education student's development of knowledge and future professional work. The analyzed data consist of interviews conducted with 22 of the 61 graduating students from the national pilot program. The study is part of a five-year longitudinal research project, illuminating professional development of newly educated teachers with a master's degree and in what way knowledge from Initial Teacher Education sustains when encountering the profession. It is important to explore the students' views of the thesis, not only because the five-year master's programs will be implemented on a national level, but also because knowledge about the significance of $R \& D$ for school teachers is needed. Our analysis shows that the results of the work with the thesis are deep knowledge, $R \& D$ competence deemed relevant for teaching, autonomy and interpersonal skills: the students reported feeling proud of their own work. The results are discussed in relation to the concepts contextual and conceptual knowledge (Afdal \& Nerland, 2012; Muller, 2009) as well as relating to theories of professionalism. To achieve excellence in a $R \& D$-based program, which can support student teachers' professional development, a systematic and evolving approach is cruical. For the future development of teacher education at master's level, this means that $R \& D$ competence must be emphasized from day one.
\end{abstract}

Keywords: teacher education, master's thesis, newly educated teacher, $R \& D$ knowledge, professional identity, conceptual/contextual knowledge

\title{
Innledning
}

I 2008 tok daværende Universitetet i Tromsø (nå UiT Norges arktiske universitet, her UiT) initiativ til en pilotering av en femårig integrert masterutdanning for lærere (Pilot i Nord, her PiN) for grunnskolens trinn 1-7 og 5-10 (heretter referert til som 1-7 og 5-10). En masterutdanning for grunnskolelærere var beskrevet i Stortingsmelding nr. 11 (2008-2009), Læreren. Rollen og utdanningen (Kunnskapsdepartementet, 2009), men Stortinget valgte likevel å gå inn for en fireårig grunnskolelærerutdanning (GLU) som nasjonal ordning (Kunnskapsdepartementet, 2010a). Regjeringen vedtok i juni 2014 at grunnskolelærerutdanningen i Norge skal være på masternivå fra 2017. Lærerutdanningene utfordres kontinuerlig av endringer i politikk og samfunn. Dette ser vi både internasjonalt og i eget land, gjennom et stadig reformtrykk (Ellis \& McNicholl, 2015; Hansén, Sjöberg \& Eilertsen, 2014; Skagen, 2006).

Stortingsmelding nr. 11 la føringer for en endret lærerrolle og -utdanning. Meldingen signaliserte at det trengtes endringer for å styrke skolens oppfølging av elevenes faglige og sosiale utvikling i et samfunn i endring (Kunnskapsdepartementet, 2009). Et sentralt argument i meldingen var at norske elever hadde svakere faglige kunnskaper og ferdigheter enn Regjeringen ønsket, et 
perspektiv som har fått bred politisk støtte også senere (Kunnskapsdepartementet, 2014). Forskningsbasert og erfaringsbasert kunnskap skulle tillegges stor vekt, og lærerens profesjonsutvikling skulle starte allerede i utdanningen. Studentene skulle bli kjent med forsknings- og utviklingsarbeid (FoU) i et profesjonsperspektiv, av hensyn til skoleutvikling, utvikling av undervisningen og av lærerens egen kompetanse. Utdanningens mål skulle være en endrings- og utviklingsorientert lærer, og med dét ble også en ny lærerrolle skissert. Høsten 2010 hadde GLU oppstart ved 19 læresteder (Munthe \& Rogne, 2015), differensiert i to løp med henholdsvis fire og tre undervisningsfag i tillegg til Pedagogikk og elevkunnskap (PEL).

Som unntak fra den nasjonale ordningen (Kunnskapsdepartementet, 2010b), startet samme høst nær 100 studenter på et femårig masterløp ved Institutt for lærerutdanning og pedagogikk (ILP) ved UiT. Den nye rammeplanen var ikke behandlet mens forarbeidet pågikk, og utdanningen ble derfor bygget direkte på Stortingsmelding nr. 11 (Kunnskapsdepartementet, 2009). En slik endring fra fireårig allmennlærerutdanning til femårig masterutdanning stiller institusjon, universitetslærere, praksisskoler og studenter overfor utfordringer av både kvalitativ og kvantitativ art. Nye studieplaner med tilhørende emneplaner ble godkjent før oppstart, men veien fra plan til realisasjon har krevd en kontinuerlig utviklingsmodus. Et kjennetegn ved PiN er at studentene skal legge grunnlaget for en forskningsbasert endrings- og utviklingskompetanse. Utdanningens struktur bygger på en reproduksjon av den finske lærerutdanningsmodellen, innført 1979. Også innholdssiden preges av finsk inspirasjon, særlig relatert til profesjonsaspektet og praksis- og forskningsorienteringen (Hansén mfl., 2014). Det første kullet fullførte utdanningen våren 2015.

Fra 2010, da både GLU og PiN ble etablert, ser vi at utvikling av forskningsbasert kunnskap i de norske grunnskolelærerutdanningene får større oppmerksomhet (Kunnskapsdepartementet, 2013, 2014). Mens land som USA og England utvikler kortere og mer praksisbaserte utdanninger (Ellis \& McNicholl, 2015), synes Norge å gå i motsatt retning. Mastergrad for grunnskolelærere representerer en vending i lærerutdanningen der forskning, faglig fordypning og profesjonsorientering vies mer oppmerksomhet. Hvordan studentene ser på masteroppgaven og dens rolle i utvikling av profesjonell identitet, vet vi mindre om. Artikkelen bygger på en intervjuundersøkelse med 22 av de første 61 studentene, gjennomført rett etter innlevering av masteroppgaven. Undersøkelsen inngår i en longitudinell studie som vil følge lærerne de fem første årene i yrket. Hovedstudien søker å belyse de nyutdannedes profesjonslæring i yrkesstarten, og hvordan det de lærer, integreres med kunnskapen utviklet i utdanningen. Studentenes perspektiver på masterarbeidet og dets betydning for deres kommende arbeid i skolen står sentralt både i hovedstudien og i denne artikkelen, hvor problemstillingen er: Hvilken relevans opplever studentene at arbeidet med masteroppgaven i 5-årig lcererutdanning har hatt for deres kompetanse som lierere? 
PiN innebærer en progressiv kunnskapsutvikling, relatert til både undervisningsfag, fagdidaktikk, profesjonsfag (tilsvarende PEL i GLU) og praksis, fra å kunne planlegge, gjennomføre og evaluere et undervisningsforløp i en skole preget av elevmangfold, til selv å kunne iverksette og analysere et forskningsbasert utviklingsarbeid innenfor rammen av egen profesjonsutøvelse og være en forskende lærer. Profesjonsfaget har hatt en sentral rolle $\mathrm{i}$ å definere, konkretisere og tilrettelegge for at begreper som integrert, forsknings- og utviklingsbasert og profesjonsrettet lererutdanning skulle gi mening. Masteroppgaven skal være et selvstendig og fortrinnsvis empirisk basert arbeid med et profesjonsfaglig (for 1-7) eller et fagdidaktisk relevant tema knyttet til norsk, matematikk, engelsk, samfunnsfag, eller kunst og håndverk (for 5-10, studentenes fag 1). Studentene kan skrive alene eller parvis. Oppgaven er på 30 studiepoeng, skal være profesjonsrelevant, gjerne inkludere et empirisk arbeid og være på 40-50 sider (UiT, 2013a, 2013b).

I artikkelen redegjør vi først for sentrale teoretiske perspektiver og begrep. Deretter beskrives metodisk tilnærming, utvalg og tiltak for å sikre studiens kvalitet. Dernest presenteres studiens funn etterfulgt av en tolkning- og diskusjonsdel hvor funnene drøftes i lys av begrepene konseptuell (conceptual) og kontekstuell (contextual) kunnskap (Afdal \& Nerland, 2012; Muller, 2009) og profesjonsteori. Studiens overførbarhet og begrensninger drøftes også. Artikkelen avsluttes med en oppsummering og utsyn mot videre forskning.

\section{Litteraturgjennomgang}

Lærerens kunnskapsfelt er sammensatt, og profesjonaliseringen av læreryrket har pågått over tid (Mausethagen, 2015). Vi må kunne se endringen av lærerutdanning til masterstudium i dette perspektivet. Oppfatninger om at profesjonell praksis blir bedre om fremtidige profesjonsutøvere i sin utdanning lærer å anvende forskningsbasert kunnskap, fremkommer i en rekke offentlige dokumenter (for eksempel Kunnskapsdepartementet, 2009, 2013) og har lenge hatt bred politisk støtte (Hansén mfl., 2014). Samtidig fremheves betydningen av en lærerutdanning som er praksisnær og profesjonsrettet. Forskrift for grunnskolelærerutdanningene understreker at institusjonene skal tilrettelegge for integrerte utdanninger som bidrar til "helhet og sammenheng mellom teori- og praksisstudier, mellom fag og fagdidaktikk og mellom fag”. Det skal være et "nært samspill med profesjonsfeltet” (Kunnskapsdepartementet, 2010a, s. 1). Hammerness (2012) viser at sterke lærerutdanningsprogram deler noen egenskaper: de har en klar visjon, de er koherente, og de har en sterk forankring i praksis. Hun presiserer at "a coherent, integrated program will result in more powerful learning for their students" (Hammerness, 2006, s. 1242).

Begrepene "integrasjon" og "koherens" fremstår som mangefasetterte i forskningslitteraturen og brukes til dels om hverandre. Zeichner (2010) hevder at én nøkkel til å lykkes med å skape integrerte programmer er et skifte til "a nonhierarchical interplay between academic, practitioner, and community 
expertise” (s. 89). Et skifte fra en kultur der den akademiske kunnskapen er autoritativ, til en kultur preget av likeverdighet, vil ifølge Zeichner kunne styrke profesjonsperspektivene i utdanningene. Det er et spørsmål om styrking av studentenes FoU-kompetanse utfordrer et slikt integrasjonsperspektiv. Ifølge Goldacre (2013) innebærer en FoU-basert lærerutdanning ikke nødvendigvis at lærere skal være forskere, men den skal sette lærere i stand til å relatere forskning og forskningsfunn til sin profesjonsutøvelse.

Hatlevik (2014) argumenterer for en forståelse av koherens i profesjonsutdanninger som opplevelse av meningsfulle sammenhenger. Det blir et mål

[...] å hjelpe studentene til å skape orden gjennom å knytte an til det studentene allerede besitter av kompetanse og erfaringer, ved å tydeliggjøre relevansen av (meningen med) innholdet i utdanningen for senere profesjonsutøvelse og ved å vise hvordan de ulike delene av utdanningen peker mot et felles mål og på ulikt vis hjelper studentene med å forberede seg for praksisperioder i utdanningen og senere profesjonsutøvelse (Hatlevik, 2014, s. 43-44).

En utfordring knyttet til utvikling av gode lærerutdanningsprogram er å ivareta kompleksiteten i det å undervise - en lærerstudent må kunne integrere kunnskaper og ferdigheter fra ulike kunnskapsområder (Darling-Hammond, Hammerness, Grossman, Rust \& Shulman, 2005).

Ifølge Muller (2009) finnes det ikke kun én profesjonell praksis. Ulikhet får betydning for utvikling av utdanningers læreplaner, som vil være bygget på tradisjoner og behovet for arbeidsdeling. Han fokuserer på relasjonen mellom kunnskapsformen og læreplanens form, og skiller mellom konseptuell og kontekstuell læreplan som analytiske begreper. Tradisjonelt har den konseptuelle læreplanen hatt som mål å produsere disiplinutøvere som er fag- og forskningsorienterte. Den kontekstuelle planen har hatt som mål å utvikle profesjonsutøvere med kunnskap av direkte relevans for arbeidslivet og yrkesutøvelsen. Innen et kunnskapsområde vil det eksistere et spenningsforhold mellom konseptuell og kontekstuell profesjonsutøvelse.

Muller (2009) bruker eksempler fra planer for ulike lærerutdanninger, der noen vektlegger praksis og klasseromsbasert innovasjon, mens andre har som mål å bidra til en generalisert kunnskap bygget på utprøvinger i praksis og eksperimenter. Han skiller mellom gamle og nye profesjoner. Gamle profesjoner, som jus og medisin, har over år utviklet en stabil kunnskapsbase og en robust profesjonell habitus. Nye profesjoner, som undervisning og sosialt arbeid, har utviklet sine kunnskapsbaser og aspirerer til selvstendighet og stabilitet på linje med de eldre profesjonene, men oppnår ikke samme respekt. Dette gjenfinner vi i norsk profesjonsforskning, hvor det har eksistert en distinksjon mellom profesjoner og semiprofesjoner (Molander \& Terum, 2008).

Afdal og Nerland (2012) bruker også begrepene "konseptuell" og "kontekstuell” i en undersøkelse av finske og norske nyutdannede læreres forhold til egen kunnskap. Forskerne ser en økende interesse for utdannings- 
design og påpeker at få studier undersøker hvordan ulike lærerutdanningsdesign påvirker de nyutdannedes kunnskapsorientering i møtet med yrket. Lærerne i utvalget hadde ulike utdanninger. Den finske utdanningen (femårig master) var forskningsbasert og koherent der den norske (allmennlærerutdanningen) var preget av mer fragmentert kunnskap og fokus på det konkrete lærerarbeidet. Størst ulikhet fremkom i bruk av profesjonelt språk. De norske lærerne brukte et mer hverdagslig språk og hadde problemer med å bruke profesjonelle språktermer til å konseptualisere utfordringene de møtte. Forskjellene gav seg utslag i hvordan lærerne posisjonerte seg som profesjonsutøvere.

Lærerutdanningskunnskapen er kompleks og mangefasettert. Utdanningene skal bidra til integrasjon av ulike kunnskapsformer for studentene, og bidra til en kunnskapsbase som gir mening til deres fremtidige profesjonsutøvelse. Med utgangspunkt i dette, og i begrepene "konseptuell kunnskapsorientering” og "kontekstuell kunnskapsorientering”, vil vi undersøke hvordan studentene ser på masteroppgaven, og hvordan de forstår den relatert opp mot sin profesjonelle identitet.

\section{Profesjonsidentitet og profesjonell identitet}

Det å bli lærer handler om å kunne identifisere seg med lærerprofesjonen, og er en prosess som studentene i studien står midt oppi. Læreridentitet er ikke noe lærere har, men noe de utvikler i sin søken etter å forstå seg selv som lærer i møtet med andre lærere og kontekstuelle krav i yrket. Her ligger grunnlaget for tolkningene av konteksten og forhandlingene som følger av tolkningsprosessen (Beijaard, Meijer \& Verloop, 2004).

Heggen (2008) trekker et skille mellom profesjonsidentitet som en kollektiv identitet felles for profesjonen, og profesjonell identitet som

[...] ei meir eller mindre medviten oppfatning av "meg” som yrkesutøvar, når det gjeld kva type eigenskapar, verdiar og haldningar, kva etiske retningslinjer eller kva ferdigheiter eller kunnskapar som konstituerer meg som ein god yrkesutøvar (Heggen, 2008, s. 324).

Utvikling av en profesjonell identitet starter i utdanningen, og for mange allerede når de selv er elever i skolen. Profesjonell identitet kan forstås som et organiserende prinsipp i læreres liv, og genereres gjennom et samspill mellom kontekstuelle, kulturelle og biografiske faktorer (Flores \& Day, 2006). Heggen drøfter, med henvisning til blant annet Thornton og Nardi (1975), begrepet anticipatory socialisation, som sikter til hvordan personer som aspirerer til å inngå i bestemte grupper, forbereder den fremtidige overgangen ved å identifisere seg med verdier og normer som harmonerer med den fremtidige rollen. Med basis i Lave og Wengers (1991) situerte læringsteori kan vi snakke om identitetsendrende deltakelse i praksisfellesskap.

I profesjonsstudier kommer ulike kunnskapsformer til uttrykk på ulike måter (Grimen, 2008). “Utvikling av ulike former for kunnskap og kompetanse krever 
ulike arbeidsformer der ulike arenaer har sine fortrinn” (Ludvigsen, 2015, s. 221). I lærerutdanningen tenker vi gjerne på undervisningsaktiviteten på institusjonen og praksisopplæringen i skolen. Begrepet "kunnskapsformer" muliggjør en differensiering relatert til forståelse av ulik kunnskap og hvordan den kommer til uttrykk som kompetanser. Ifølge Ludvigsen fører distinksjonen mellom teori og praksis "ofte til at vi mister muligheten til å se på relasjonen mellom ulike kunnskapsformer og hvordan disse er gjensidig konstituert i handlinger, og selve grunnlaget for en profesjonell praksis [...] Det er selve samspillet mellom kunnskapsformene som skaper handlinger og det profesjonelle arbeidet” (Ludvigsen, 2015, s. 222). Dette innebærer at studentene både forstår hvordan ulike kunnskapsformer spiller sammen, og at de ser muligheter og begrensninger i sin egen kunnskapsbase på et gitt tidspunkt. Ifølge Ludvigsen er det urealistisk å tro at studentene er lærere med en høy grad av ekspertise når de kommer ut i skolen. Starten på yrkeskarrieren vil alltid være en periode for utprøving og læring knyttet til selve profesjonsutøvelsen, og den vil foregå i kollegial samhandling (Jakhelln, 2011; Smeby \& Heggen, 2014). Vi vil her bygge videre på denne forskningen når vi undersøker betydningen av FoU-kompetansen PiN legger opp til, og hvordan denne henger sammen med studentenes utvikling av profesjonsidentitet og deres egen profesjonelle identitet.

\section{Metode}

Denne intervjustudien har en kvalitativ tilnærming innen et konstruktivistisk og fortolkende forskningsparadigme. Intervjustudien er en del av en longitudinell studie som blir avsluttet i 2020, med årlige intervjuer på våren og e-postkorrespondanse ved årsskiftene. Bortsett fra ett intervju i august, ble intervjuene gjennomført våren 2015, rett etter at studentene hadde levert masteroppgavene, men før de var kjent med resultatene. Intervjuene forløp som tematisk fokuserte samtaler om studentenes syn på utdanningens innhold og relevans. Samtalene ble strukturert av en intervjuguide bestående av fem deler: 1) bakgrunnsinformasjon og motivasjon for lcererutdanning på masternivå, 2) syn på utdanningens oppbygging og innhold, 3) masteroppgaven og FoU, 4) jobbutsikter og 5) erfaring med integrasjon. Guiden inneholdt nokså nøyaktige spørsmålsformuleringer i en angitt rekkefølge. Hvert intervju varte i ca. en time. Artikkelforfatterne transkriberte deretter lydopptak av intervjuene. I transkripsjonen la vi vekt på en mest mulig korrekt gjengivelse av studentutsagnene. Intervjuene foregikk på lærestedet, bortsett fra to, som av praktiske årsaker gikk via Skype.

Det transkriberte datamaterialet ble bearbeidet ved hjelp av en induktiv, kategoribasert analysestrategi (Thagaard, 2006, s. 133). Første steg i analyseprosessen besto $\mathrm{i}$ at alle tre forskerne leste grundig gjennom intervjuene. Vi 
utarbeidet deretter en sammenfatning av de viktigste temaene i materialet. Kvale (2004, s. 126) beskriver prosessen som “meningsfortetting”. Neste trinn var å dele teksten inn i kategorier med begreper som sa noe om innholdet i kategoriene. Kategorisering av materialet innebærer at informasjon om det samme temaet samles i en kategori. De begrepene som ble benyttet som koder, representerte temaer som studentene snakket om. Miles og Huberman (1994) kaller dette induktiv koding. Vi valgte denne strategien fordi induktiv koding kan være hensiktsmessig når en skal undersøke fenomener som ikke har vært gjenstand for tidligere forskning (Grønmo, 2004, s. 38). Hvordan lærere og lærerstudenter opplever ulike kunnskapsformer har imidlertid tidligere vært gjenstand for forskning. Vi har likevel valgt en induktiv tilnærming fordi det i vår sammenheng er avgjørende å kunne belyse informantenes egne perspektiver. I arbeidet med å kategorisere det empiriske materialet har vi søkt etter uttalelser knyttet til masteroppgaven og kompetansen studentene mener dette har gitt av betydning for profesjonsutøvelsen. Til slutt satt vi igjen med fire kategorier: a) dybdekunnskap, b) forsknings- og utviklingskompetanse (FoU), c) samarbeidskompetanse og selvstendighet og d) stolthet. Kategoriene blir nærmere presentert og definert i resultatseksjonen.

\section{Beskrivelse av utvalget}

Studien er basert på et strategisk utvalg, altså informanter som har kvalifikasjoner som er strategiske ut fra problemstillingen (Thagaard, 2006). Utvalget fremkom ved selvseleksjon etter en skriftlig invitasjon som inneholdt en grundig beskrivelse av studien. Da studien er longitudinell, har det vært viktig å få med et tilstrekkelig antall deltakere til at den tåler et visst frafall.

Utvalget består av 22 studenter, 7 menn og 15 kvinner, og representerer om lag $1 / 3$ av dem som fullførte utdanningen våren 2015. Åtte av studentene fulgte studieprogrammet for 1-7, og fjorten programmet for 5-10. Av de totalt 61 studentene som leverte, var $40 \%$ menn (i utvalget er det litt over $30 \%$ menn). Da intervjuene ble gjennomført, hadde studentene nylig levert masteroppgavene sine, men de var ennå ikke vurdert. Noen hadde vært gjennom flere jobbintervjuer, men de fleste hadde ikke fått jobb. Vi ønsket å fokusere på oppnådd kunnskap, og vurderte tidspunktet rett etter innlevering som det gunstigste. På dette tidspunktet er studentene sannsynligvis verken forstyrret av oppgavearbeid eller følelser knyttet til vurdering, og dessuten er de fremdeles i studentrollen.

\section{Tiltak for å sikre reliabilitet og validitet}

Artikkelens tre forfattere er alle ansatt som forskere og pedagoger ved ILP. Den ene har undervisnings- og forskningsoppgaver som ikke er knyttet til masterutdanningen. De to andre underviser i profesjonsfaget i begge programmene, og har veiledet til sammen fire av utvalgets studenter på masteroppgaven. Det er også disse to forskerne som har gjennomført intervjuene. PiN ble utviklet 
parallelt med at studentene gjennomførte sin utdanning, noe som førte til tette relasjoner mellom lærerutdannerne og studentene. Vi kan derfor ikke utelukke at dette kan ha hatt innvirkning på studentene i intervjusituasjonen.

Det er ikke uvanlig at profesjonsforskning utføres av ansatte ved profesjonsutdanningene (Leseth \& Tellmann, 2014, s. 16), og ifølge Haug gjelder også dette nyere norsk forskning på lærerutdanning. Haug er kritisk til at forskere studerer egen institusjon, studenter og kolleger fordi den kritiske distansen kan svekkes (Haug, 2010, s. 18). Vi er enige med Haug i at nærhet til data kan representere en svakhet, men i likhet med Molander og Smeby (2013) mener vi likevel at profesjonsforskerens nærhet til feltet også kan være en ressurs, særlig med hensyn til tilgang på informanter og til kontekstforståelse. For å sikre kvaliteten i forskningen har vi bestrebet oss på å ha en refleksiv innstilling til forskningsprosessen, datainnsamlingen og datamaterialets pålitelighet (Leseth \& Tellmann, 2014, s. 15). Dette bygger på en erkjennelse av at nøytrale og objektive observasjoner ikke er mulig, og at all forskning vil være preget og dermed begrenset av forskerens posisjon og erfaringsbakgrunn.

$\mathrm{Vi}$ har bestrebet oss på å beskrive alle fasene i forskningsprosessen transparent, samt være bevisste på - og åpne om - våre roller. Veiledning er et relasjonelt forhold mellom student og veileder, og som nevnt har to av forfatterne fungert som veiledere for noen av studentene. Intensjonen var i utgangspunktet at studentene ikke skulle intervjues av sin veileder, men av praktiske årsaker ble dette likevel tilfellet for tre av fire studenter. For å redusere faren for radikal påvirkning i intervjusituasjonen, ble intervjuene gjennomført etter at veiledningsforholdet var opphørt. Vi oppfordret studentene til å svare ærlig. Den av artikkelens tre forfattere som ikke har tilknytning til lærerutdanningene, har bidratt ytterligere til å sikre distanse til det empiriske materialet. Det er reliabilitetshensyn som ligger til grunn for denne forskertrianguleringen i analysen av datamaterialet.

Vi har fulgt nasjonale forskningsetiske retningslinjer utgitt av NESH (Den nasjonale forskningsetiske komité for samfunnsvitenskap og humaniora), og studien er godkjent av NSD (Norsk samfunnsvitenskapelig datatjeneste). Studentene ble informert om studiens opplegg og formål, og samtlige har gitt skriftlig samtykke til å delta. Deltakerne vil få ta del i studiens resultater gjennom årlige informasjonsbrev og tilgjengelige kanaler for forskning, som denne artikkelen er et eksempel på. Relatert til hovedstudien vil dette kunne øke validiteten på sikt.

\section{Resultater}

Studiens siktemål er som nevnt studentenes opplevelse av masteroppgavens relevans for kompetanseutviklingen som lærer. Kategoriene er basert på temaer som er særlig fremtredende i materialet: dybdekunnskap, FoU-kompetanse, 
samarbeidskompetane og selvstendighet, og stolthet. Dybdekunnskap og FoUkompetanse blir kommentert av samtlige studenter, og er de mest fremtredende kategoriene.

\section{Dybdekunnskap}

Studentene opplever at arbeidet med masteroppgaven har gitt dem dybdekunnskap om et tema som er relevant for yrkesutøvelsen, og at dette gir dem en faglig trygghet og faglig fordypning som er betydningsfull når de skal jobbe i skolen. De to følgende utsagnene er representative for det flere av studentene sier:

Det å gå i dybden av noe er stort, samtidig som det er fagkunnskapen vi fokuserer på. Den har gitt meg masse, selv om jeg var negativ til masteroppgaven i fjor. Jeg har gjort ting jeg vil ta med meg inn i skolen.

Tror jeg blir en bedre lærer av at jeg har fått en master. Fått mye innsikt i et felt jeg ikke kunne noe om fra før. Lurt å tenke at man hele tiden kan forandre seg, forbedre undervisningen, og systemet egentlig.

I tillegg til at et flertall opplever at arbeidet med masteroppgaven har bidratt til dypere fagkunnskap, er det også studenter som sier at arbeidet med masteroppgaven har styrket profesjonskunnskapen deres. Flere av studentene gir uttrykk for at de forventet at masterarbeidet skulle være direkte relevant for yrkesutøvelsen. Andre er litt mer tvilende, og som en student sier: “Jeg lærte vanvittig mye av masteren, men jeg føler kanskje ikke at den har bidratt direkte til min lærerrolle.” Flere studenter fremholder at masterarbeidet på et vis fjernet dem fra profesjonen, siden de ikke har ordinær praksis det femte året, men i stedet tilnærmer seg skolen i en forskerrolle.

På en måte skulle jeg ønske at masteren var litt mer sånn som bacheloren i aksjonslæring. Da var vi på en måte lærere mens vi forsket! [...] Vi hadde selv undervisningen, og brukte prosjektet vårt i undervisningen og så vurderte det etterpå.

En annen student sier om bachelorarbeidet: "Da fikk vi jo være i praksis og gjøre en utforskning. [...]. Vi hadde mye tydeligere kriterier og rammer." Studentene er opptatt av at det de gjør, skal bidra til at de utvikler seg som lærere. Dette ser også ut til å ha vært utslagsgivende for hva studentene valgte å skrive om. Flere fordypet seg i temaer som kunne knyttes direkte til bruk i skolen, slik som lesing og muntlig aktivitet.

\section{FoU-kompetanse}

Det er noen stikkord som går igjen hos samtlige studenter når de snakker om sin egen utvikling gjennom studiet. De er opptatt av utviklingsorientering, av livslang læring, av betydningen av å være undersøkende, av å kunne gjøre små 
prosjekter og av å være oppdatert på utviklingen av fag og skole. "Det sitter i ryggraden å tenke utviklingsorientert," er det flere som sier.

Skolen utvikler seg, du har ulike elever, du utvikler deg. Det er jo det å hele tida klare å ha et åpent blikk og bruke det en kan på nye måter, involvere andre, kunne reflektere i lag. Jeg kjenner jeg har et godt utgangspunkt både fra bacheloren og fra masteren og de ulike oppgavene vi har hatt i fagene.

Studentene forteller at masteren har gitt dem økt innsikt i hva FoU er og hvordan de kan bruke det for å utvikle både sin egen praksis og sin fremtidige arbeidsplass. Å ha lært seg å finne frem til forskningsbasert kunnskap, trekker de frem som en sentral del av profesjonskunnskapen. De ser dessuten på den vitenskapelige tilnærmingen til fag og profesjon som et verktøy for å utvikle seg videre, og forteller at de "har kunnskap om observasjoner, intervju og andre metoder som kan vise hvordan elevene opplever sin skolehverdag”. Studentene synes også det er betydningsfullt å kunne bruke vitenskapelige metoder til å utvikle kunnskap om egen og andres praksis. Flere kobler dette til kunnskap om aksjonsforskning og aksjonslæring, som sto sentralt i bachelorarbeidet. Mange hadde planer om å følge dette opp i masteren, men de fleste fant ut at de ikke rakk en slik tilnærming.

Flere har vært på jobbintervju og merket seg at arbeidsgivere gjerne vektlegger fag- og endringskompetanse. En forteller: "De var veldig interessert i den faglige fordypningen og ønsker å bruke meg som en ressurs i realfag for hele skolen.” Studentene er opptatt av å bruke kunnskapene sine, og de mener de vet hvordan de skal orientere seg i ulike kunnskapsfelt. De poengterer at "det å vite hvordan man finner relevant forskning og se hva andre har gjort" er betydningsfullt, og at utdanningen har gitt grunnlag for å utvikle egen kompetanse og bidra til felles utviklingsarbeid. En student sier: "Noe av det viktigste vi har lært i denne utdanningen er å forske på egen praksis!”, men studenten viser også en nøktern realisme: "Jeg vil nok ikke forske så mye det første året, da vil jeg ha nok med å komme i gang.”

Noen uttrykker også bekymring for hvordan de vil reagere i møte med yrkeshverdagen. De ser seg selv som ambisiøse, men undres over om det de er opptatt av, er utopisk å gjennomføre i en hektisk hverdag. En student beskriver sin bekymring slik:

FoU-kompetanse er veldig viktig som lærer. Det blir spennende å se om jeg får brukt kunnskapen jeg har, eller om det blir sånn at man sitter med mye kunnskap som går i glemmeboka. Jeg mistenker at det blir litt sånn. Litt basert på følelsen fra jobbintervjuene, at det faglige ikke er viktig, men hvordan du er som person og hvordan du klarer å knytte deg til andre. 
Studentene ser at det kan være vanskelig for lærere å ha tid og kapasitet til å initiere og gjennomføre utviklingsprosjekter. De mener likevel at lærere må ha som mål å utvikle profesjonspraksisen sin. Flere uttrykker usikkerhet om hvordan skolene vil ta imot kompetansen deres. "Vet andre om utdanningen vår? Er vår spesielle utdanning kjent ute i skolene?” De er bekymret for at de fremtidige kollegene skal være for ulike dem selv.

Flere er opptatt av forholdet mellom skole og samfunn. De er opptatt av at skolen må endre seg i takt med samfunnsutviklingen, men at skolen, basert på kunnskap, også må kunne være kritisk til tradisjoner og nye utviklingstrekk. "Kanskje vi kan være en drivkraft til at skolen kommer litt raskere, eller kommer litt nærmere den utviklingen samfunnet er i, i forhold til skolen?” Studenten er redd for at skolen preges av "sånn har det alltid vært, sånn skal det være”. En annen student beskriver forholdet slik:

[...] det er viktig å ha fokus på det [forskning] i utdanningen fordi du lærer deg en annen måte å tenke på, [...] for dette her [skolen] er ikke strømlinjeformet og det er ikke en pakkesentral. Det er mennesker vi har med å gjøre. Det er klart at det vi skal lære bort i skolen skal også henge på greip med det som skjer i samfunnet, og da er vi nødt å hele tiden [følge med].

Studentene er spørrende til om skolen kan være en arena for lærerforskning. "FoU kan ha betydning, men det kommer an på eget initiativ." En student mener det hadde vært "en god idé om skolene tok mere tak i det, og ga litt frikjøp for at lærere kunne skrive og publisere”. Studenten mener det kan hjelpe å få lærernes stemmer mer ut. "Da kan det bli kunnskapsdeling - en mulighet for å få en skole som består av forskende lærere.” Forskning er blitt en del av disse kommende lærernes profesjonskunnskap. Fire studenter antyder at de kan tenke seg å gå videre med forskning og kanskje en gang ta en doktorgrad. Én tenker seg en fremtid som lærerutdanner.

\section{Samarbeidskompetanse og selvstendighet}

Samtlige fremhever betydningen av samarbeid. Flere valgte å skrive masteroppgaven sammen med noen, og mener at samarbeidskompetansen de utviklet gjennom masterarbeidet, er relevant for profesjonsutøvelsen. De ser samarbeid som noe som er positivt, men også krevende: "Vi har jo også lært mye av det å jobbe sammen fordi det er jo en prøvelse det også, virkelig! [...] Det har vært utfordrende, veldig utfordrende.” Samarbeidet ses som betydningsfullt for utvikling av evne til profesjonelt samarbeid. “[...] når du kommer ut i skolen - du må jo jobbe mye selvstendig og på en måte strukturere dagen din, kanskje ikke så mye selvstendig, du må i alle fall ta ansvar da for at du bidrar til fellesskapet.” Studenten tror utdanningen har gitt studentgruppen et annet syn på forskning og samarbeid enn det som har vært det tradisjonelle synet i skolen. Viktigheten av at lærere kan samarbeide om sin faglige og pedagogiske utvikling, er gjennomgående i materialet. 
Masteroppgaven har utfordret studentenes selvstendighet. Dette kommer til uttrykk gjennom uttalelser som: "vi har styrt alt sjøl”, "vi måtte kontrollere alt sjøl”, "stå på egne bein”, "tenke selv”. Flere studenter sier at det å ha fătt erfaring med å jobbe selvstendig, er noe som er positivt med tanke på yrkeslivet. Følgende er representativt for flere: “ $\AA$ få jobbe med noe over en lengre periode. Å lære hvordan man må strukturere hverdagen sin. Det er viktig når en kommer ut i skolen og har ansvar for å tilrettelegge sin arbeidshverdag.” Selvstendighet kommer også til uttrykk gjennom studentenes vilje til å bidra til utviklingsprosjekter på sin fremtidig arbeidsplass. En student beskriver dette slik: «Jeg kan være med å dra i gang prosjekter på skolen. FoU-fokuset. Jeg tror det er det som har vært den største fordelen med master, å få det perspektivet inn.”

\section{Stolthet}

Studentene gir spontane uttrykk for stolthet over å ha gjennomført en master, og flere omtaler det som forskning. De er svært positive til å møte arbeidslivet med sin nyervervede kompetanse.

Jeg er veldig stolt over å ha gjort dette arbeidet. Jeg føler at det gir meg noe mer. Det betyr noe å ha en mastergrad og ha skrevet en masteroppgave. Jeg har forsket på noe jeg kan få bruk for. En ting er tema og oppgaven, det andre er redskapet, hva forskningen gir meg både i bacheloroppgaven og nå. Det at læringen er et verktøy jeg kan bruke ute i skolen. Som en utvikling du ikke kan stoppe.

En annen student sier: "Jeg har funnet ut av ting. Det er noe jeg står inne for og det er noe jeg er stolt over. Det har vært veldig givende.” En tredje sier: “Jeg er stolt av produktet, over at jeg har klart å gjennomføre dette. Over frihetsfølelsen ved valget [av utdanning]. Jeg ville bli lektor!” Kunnskapsutviklingen i masterarbeidet gir muligheter i fremtiden. Flere vil gjerne gi masteroppgaven sin til rektor på den kommende arbeidsplassen. På oppfordring fra utdanningsministeren selv er samtlige masteroppgaver sendt Kunnskapsdepartementet, noe som også bidrar til følelsen av å ha gjort et betydningsfullt arbeid. Studentene er opptatt av at de er de første og at de derfor har gitt viktige utviklingsbidrag til masterutdanningen.

\section{Diskusjon}

Formålet med artikkelen er å belyse hvordan lærerstudentene opplever at masteroppgaven er relevant for den fremtidige profesjonsutøvelsen. Tre av de fire kategoriene vi kommenterer i resultatseksjonen, er også kompetansemål beskrevet i studieplanene for PiN, nemlig dybdekunnskap, FoU-kompetanse, og samarbeid og selvstendighet (UiT, 2013a, 2013b). I tillegg fremkommer en fjerde kategori i datamaterialet, stolthet. Studentene er de første i Norge som har skrevet masteroppgave i en integrert femårig grunnskolelærerutdanning. De 
anser FoU-kompetansen og masteroppgaven som relevant både for videreutvikling av fagkunnskap og som et grunnlag for å initiere endring og utvikling i skolen. Samtidig er de noe spørrende til masterarbeidets direkte relevans for lærerarbeidet, til hvorvidt de vil få nyttiggjøre seg av fag- og forskningskompetansen sin i skolen, og til hvordan den profesjonelle identiteten de er i ferd med å utvikle, vil bli oppfattet. Vi vil diskutere resultatene i lys av begrepene "konseptuell kunnskap", "kontekstuell kunnskap" og "profesjonell identitet”. Begrepene kan gi grunnlag for å forstå studentenes kunnskapsutvikling.

\section{Konseptuell og kontekstuell kunnskapsorientering i utdanningen}

Stortingsmelding nr. 11 (Kunnskapsdepartementet, 2009) la føringer for en endringsorientert og forskningsbasert lærerrolle. Masterutdanningen for grunnskolelærere, som innføres nasjonalt fra 2017, bygger videre på denne visjonen (Kunnskapsdepartementet, 2014). Utviklingen står i kontrast til den tidligere allmennlærerutdanningen, utviklet innenfor en kontekstuell læreplan, der det å utdanne kunnskapsrike profesjonsutøvere orientert mot en erfarings- og klasseromsbasert praksis forankret i lokale behov, sto sentralt (Afdal \& Nerland, 2012). Med lærerutdanning på masternivå vil vi kunne påregne at kunnskapsbasene i utdanningene endres, og at en mer konseptuell kunnskap gjør seg gjeldende. Hvordan spenningsforholdet mellom konseptuell og kontekstuell kunnskap håndteres i ledelsen av utdanningene, og videre av studentene, vil være av betydning for den videre utviklingen av profesjonen (Muller, 2009).

Studentene i undersøkelsen opplever masterarbeidets faglige fordypning som noe nytt og relevant. De ser metodekompetansen som et verktøy for å utvikle en mer systematisk innsikt i elevenes hverdag og læringsarbeid. Kunnskapsbasen de utvikler gjennom utdanningen, gir studentene en opplevelse av å ha et faglig grunnlag for å håndtere utfordringer som de kan regne med å møte i arbeidet som lærer. Dette gir dem en form for trygghet med tanke på den kommende profesjonsutøvelsen. Vi kan forstå dette som at studentene ser seg i stand til å koble konseptuell og kontekstuell kunnskap.

Studentene mener de kan innhente teoretisk kunnskap om skolefeltet, og de kan lese, fortolke og anvende relevant forskningslitteratur for å håndtere utfordringer i praksisfeltet. Noen har også tanker om hvordan de kan sette i gang mindre FoU-prosjekter i skolehverdagen, og har i jobbintervjuer erfart at FoUkompetanse er etterspurt. Studentene føler seg kompetente til å vurdere både egen og andres praksis med et analytisk blikk. Vi tolker dette som at studentene gjennom utdanningen har lært å se sammenhenger som de opplever som meningsfulle (Hatlevik, 2014). Kompetansen deres representerer både konseptuell og kontekstuell kunnskap, som i noen grad kan sies å være ny i grunnskolen og i lærerrollen (Jakhelln, 2014). Studentene synes å representere en ny type lærer - den forskende læreren, og posisjonerer seg som profesjons- 
utøvere (Afdal \& Nerland, 2012) med en bevissthet på lærerens ansvar for endring og utvikling.

\section{Profesjonell identitet}

Studentene er intervjuet på slutten av utdanningen. På dette tidspunktet har noen av dem fått jobb, andre venter på resultatet fra jobbintervjuene. De uttrykker en stolthet over å ha gjennomført en mastergrad, men er usikre på sin profesjonelle identitet. Vil de passe inn, eller vil de avvike fra sine kolleger? Vil de klare å bevare sin endringskompetanse og bli forskende lærere, eller vil de tilpasse seg en mer tradisjonell lærerrolle i en presset hverdag? De nyutdannede lærerne skal fylle en dobbeltrolle der de er både praktikere og forskere, og kan ifølge Jarvis (2002) betegnes som praktiker-forskere. Masterstudentene uttrykker usikkerhet over hvordan deres begynnende profesjonelle identitet står i forhold til verdier og normer de oppfatter som rådende blant dagens lærere. Den profesjonelle identiteten som studentene har utviklet i løpet av utdanningsløpet, står i motsetning til tidligere forskning, som viser at studenter gjerne tilpasser seg det de anser som rådende i profesjonen (Heggen, 2008).

I profesjonsutdanningene kan forholdet mellom teori og praksis ofte være utfordrende, noe mange forskere retter søkelyset mot (Heggen, 2005). Mye tilsier at studentene i undersøkelsen har overvunnet dette uproduktive perspektivet på kunnskap (Ludvigsen, 2015). Ludvigsen påpeker også at samspillet mellom kunnskapsformene først blir produktivt når det utspiller seg i profesjonelle sammenhenger. Som flere av studentene uttrykker, så er det først når de er i jobb de vil se mulighetene og begrensningene i kunnskapen sin.

\section{Kunnskapsgrunnlag og profesjonsutøvelse}

Avslutningsvis vil vi rette søkelyset mot kunnskapsgrunnlaget masterstudentene tar med seg ut i yrkeslivet. Verdier og normer studentene har utviklet gjennom PiN synes ikke fullt kompatible med det de forventer å møte i skolen. Studentene er klar over at de vil kunne virke utfordrende på kolleger og ledelse i skolen og at de selv vil kunne bli utfordret på sin kunnskap. De synes til en viss grad å være forberedt på en slik yrkesstart, og synes i stand til å konseptualisere utfordringene de forventer å møte i yrket i profesjonelle språktermer (jf. Afdal \& Nerland, 2012). Studentgruppens profesjonsidentitet knyttes til en forskningsbasert yrkesutøvelse. De synes å ha sett meningsfulle sammenhenger (jf. Hatlevik, 2014) mellom kunnskapen de har utviklet gjennom masterarbeidet og den kommende profesjonsutøvelsen.

Når studentene stiller spørsmål ved masterarbeidets bidrag til utvikling av lærerrollen, viser de at de opplever et spenningsforhold mellom forskerrollens konseptuelle kunnskapsgrunnlag og den kontekstuelle kunnskapen som lærerens hverdagsarbeid tradisjonelt har bygget på (Muller, 2009). Studentene fremhever en indirekte relevans av den konseptuelle kunnskapen, forstått som kunnskap 
om systematisk datainnsamling, evne til analyse og kunnskapsutvikling om egen virksomhet. I denne ligger kunnskapsgrunnlaget for å utvikle praksis. FoUfokuset i utdanningen og fordypningen i masterarbeidet, synes å ha bidratt til en integrert kunnskapsbase som studentene mener kan være relevant i møte med en lærerhverdag hvor mer kontekstuelle kunnskapsformer er gjeldende. Samtidig som studentene ser muligheter, ser de også hvordan utnyttelsen av deres kompetanse, vil være avhengig av konteksten de møter.

Hvis studentenes kunnskap viser seg å være relevant for profesjonsutøvelsen deres, kan vi forvente at de vil utfordre dagens praksis. Hva slags implikasjoner vil en ny generasjon med forskende lærere kunne gi på lang sikt? Vi kan tenke oss ulike scenarier hvor sterke og utviklingsorienterte skoler vil kunne gi grunnlag for videre utvikling av de nyutdannedes FoU-kompetanse, slik noen hadde fått et inntrykk av allerede i jobbintervjuer. Ved skoler som er sterke på kontekstuell kunnskap, kan vi forvente at den mer konseptuelle kunnskapen de nyutdannede har fra utdanningen, vil kunne oppfattes som utfordrende av kolleger som ønsker å beskytte sin egen tradisjon. Også dette scenariet ser vi tendenser til i materialet fra jobbintervjuene. Å starte karrieren på slike skoler kan gi utfordringer for de nye masterlærerne (Jakhelln, 2011, 2014). Studentenes usikkerhet viser at det er behov for videre utvikling av de to masterutdanningene. Det kreves et systematisk og kontinuerlig utviklingsarbeid ved institusjonene for å gi masterarbeidet kvaliteter som kan støtte opp om studentenes utvikling som profesjonelle lærere i en forskningsbasert yrkesutøvelse i ulike skolekontekster.

Undersøkelsen besvarer spørsmålet om hvilken relevans lærerstudenter opplever at det å skrive masteroppgave har hatt for deres kompetanse som fremtidige lærere. Undersøkelsens formål er ikke å gi generaliserbare svar, men å gi indikasjoner på opplevelse av relevans ved å undersøke det eneste kasuset som foreløpig finnes i Norge. Svarene er såpass tydelige at det er urimelig å avskrive dem på bakgrunn av eventuelle svakheter som følger av at to av forskerne også har vært involvert i feltet som lærerutdannere. Undersøkelsen gir en tydelig positiv indikasjon på at masteroppgaven på tidspunktet intervjuene ble gjennomført, oppleves som et relevant bidrag til profesjonell kompetanse ved denne lærerutdanningsinstitusjonen. Først når studenter ved flere norske lærerutdanninger har avlagt mastereksamen med oppgave, vil det være mulig å gi mer generaliserbare svar.

\section{Oppsummering og konklusjon}

Vi har i denne artikkelen rettet oppmerksomheten mot de første som har tatt en integrert mastergrad i grunnskolelærerutdanning i Norge. Hovedspørsmålet har vært hvilken relevans studentene opplever at masteroppgaven har for den fremtidige profesjonsutøvelsen deres. Resultatene viser masterstudenter som er svært opptatt av FoU og forskningsbasert kunnskap. Arbeidet med master- 
oppgaven har gitt dem dybdekunnskap de mener er relevant for profesjonsutøvelsen, og prosessen med å gjennomføre masteroppgaven har ført til selvstendighet og evne til samarbeid. Resultatene viser at disse studentene, med sin faglige fordypning og FoU-kunnskap, representerer en ny lærerrolle: den forskende læreren. Selvstendighet, samarbeidskompetanse og stolthet er egenskaper som vil ha avgjørende betydning om de skal kunne fungere i en skole som tradisjonelt har hatt andre verdier i fokus.

Det gjenstår fortsatt et spørsmål om hvor holdbar disse studentenes kunnskapsbase er i møte med en profesjon og en skolevirkelighet med andre kunnskapsformer i fokus. Reformtrykket i lærerutdanningene er omfattende, og krevende for institusjonene. Denne studien viser også at de kommende lærerne kan ha en profesjonell utrygghet knyttet til sin egen kompetanse. Dette er noe som stiller store krav til de institusjonene som skal utvikle nye masterutdanninger for grunnskolelærere.

Undersøkelsen som denne artikkelen bygger på, inngår i en longitudinell studie som vil følge de 22 nyutdannede lærerne gjennom de fem første årene i yrket. Studiens mål er å undersøke hvor relevant masterutdanningen viser seg å være for studentene når de går ut i jobb som lærere. Når grunnskolelærerutdanningene i Norge fra 2017 skal være på masternivå, trenger vi å utvikle en forskningsbasert kunnskap om hva dette innebærer i utdanningen og for profesjonsutøvelsen.

\section{Referanser}

Afdal, H. \& Nerland, M. (2012). Does Teacher Education Matter? An Analysis of Relations to Knowledge among Norwegian and Finnish Novice Teachers. Scandinavian Journal of Educational Research, 58(3), 281-299.

Beijaard, D., Meijer, P. C. \& Verloop, N. (2004). Reconsidering research on teachers' professional identity. Teaching and Teacher Education, 20(2), 107-128. doi: http://dx.doi.org/10.1016/j.tate.2003.07.001

Darling-Hammond, L., Hammerness, K., Grossman, P., Rust, F. \& Shulman, L. (2005). The design of teacher education programs. I L. Darling-Hammond \& J. Brandsford (red.), Preparing teachers for a changing world: What teachers should learn and be able to do (s. 390-441). San Fransisco: Jossey-Bass.

Ellis, V. \& McNicholl, J. (2015). Transforming Teacher Education: Reconfiguring the Academic Work. London, New Dehli, New York, Sydney: Bloomsbury Academic.

Flores, M. A. \& Day, C. (2006). Contexts which shape and reshape new teachers' identities: A multi-perspective study. Teaching and Teacher Education, 22(2), 219-232. doi: http://dx.doi.org/10.1016/j.tate.2005.09.002

Goldacre, B. (2013). Teachers! What would evidence based practice look like? Bad Science. Hentet fra http://www.badscience.net/2013/03/heres-my-paper-on-evidence-and-teachingfor-the-education-minister/

Grimen, H. (2008). Profesjon og kunnskap. I A. Molander \& L. I. Terum (red.), Profesjonsstudier (s. 71-86). Oslo: Universitetsforlaget.

Grønmo, S. (2004). Samfunnsvitenskapelige metoder. Bergen: Fagbokforlaget. 
Hammerness, K. (2006). From Coherence in Theory to Coherence in Practice. Teacher College Record, 108, 1241-1265.

Hammerness, K. (2012). Examining Features of Teacher Education in Norway. Scandinavian Journal of Educational Research, 57(4), 400-419. doi: http://dx.doi.org/10.1080/00313831.2012.656285

Hansén, S.-E., Sjöberg, J. \& Eilertsen, T. V. (2014). Finske reformideer i norsk lærerutdanningsdiskurs. I K. A. Røvik, T. V. Eilertsen \& E. M. Furu (red.), Reformideer $i$ norsk skole. Spredning, oversettelse og impelmentering (s. 168-193). Oslo: Cappelen Damm.

Hatlevik, I. K. R. (2014). Meningsfulle sammenhenger. En studie av sammenhenger mellom lcring på ulike arenaer og utvikling av ulike aspekter ved profesjonell kompetanse hos studenter i sykepleier-, lerer- og sosialarbeiderutdanningene (Doktoravhandling, Høgskolen i Oslo og Akershus, Oslo). Hentet fra https://oda.hio.no/jspui/handle/10642/2397

Haug, P. (2010). Kvalifisering til leraryrket. Oslo: Abstrakt.

Heggen, K. (2005). Fagkunnskapens plass i den profesjonelle identiteten. Norsk pedagogisk tidsskrift, 89(06), 446-460.

Heggen, K. (2008). Profesjon og identitet. I A. Molander \& L. I. Terum (red.), Profesjonsstudier (s. 321-332). Oslo: Universitetsforlaget.

Jakhelln, R. (2011). Alene - sammen. Nyutdannede læereres profesjonsutvikling i veiledning og kollegial samhandling (Doktoravhandling). Tromsø: Universitetet i Tromsø.

Jakhelln, R. (2014). Øyet som ser. Om den nye læreren som idebærer og fremmed. I K. A. Røvik, T. V. Eilertsen \& E. M. Furu (red.), Reformideer i norsk skole. Spredning, oversettelse og implementering (s. 230-253). Oslo: Cappelen Damm.

Jarvis, P. (2002). The Theory \& Practice of Teaching. London: Routledge.

Kunnskapsdepartementet. (2009). Læreren. Rollen og utdanningen. (St.meld. nr. $112008-$ 2009). Hentet fra https://www.regjeringen.no/no/dokumenter/stmeld-nr-11-2008-2009/id544920/

Kunnskapsdepartementet. (2010a). Forskrift om rammeplan for grunnskolelcererutdanningene for 1.-7. trinn og 5.-10. trinn. Oslo: Regjeringen, Kunnskapsdepartementet. Hentet fra: http://www.regjeringen.no/nb/dep/kd/dok/lover_regler/forskrifter/2010/forskrift-omrammeplan-for-grunnskolelar.html?id=594357

Kunnskapsdepartementet. (2010b). Rundskriv F-05-10. Forskrift om rammeplan for grunnskolelcererutdanningene for 1.-7. trinn og 5.-10. trinn og forskrift om rammeplan for de samiske grunnskolelærerutdanningene for 1.-7. trinn og 5.-10. trinn (21.03.2010). Hentet fra: https://www.regjeringen.no/no/dokumenter/rundskriv-f-05-10-forskrifter-omny-grun/id598615/

Kunnskapsdepartementet. (2013). Lange linjer - kunnskap gir muligheter. (St.meld. nr. 18 2012-2013). Hentet fra https://www.regjeringen.no/no/dokumenter/meld-st-1820122013/id716040/

Kunnskapsdepartementet. (2014). Lærerløftet. På lag for kunnskapsskolen. Strategi. Hentet fra

https://www.regjeringen.no/globalassets/upload/kd/vedlegg/planer/kd_strategiskole_web. pdf

Kvale, S. (2004). Det kvalitative forskningsintervju. Oslo: Gyldendal Akademisk.

Lave, J. \& Wenger, E. (1991). Situated learning legitimate peripheral participation. Cambridge: Cambridge University Press.

Leseth, A. B. \& Tellmann, S. M. (2014). Hvordan lese kvalitativ forskning? Oslo: Cappelen Damm. 
Ludvigsen, S. (2015). Epilog, fagfornyelse, dybdelæring og progresjon i lærerutdanning. I U. Rindal, A. Lund \& R. Jakhelln (red.), Veier til fremragende læererutdanning (s. 221-228). Oslo: Universitetsforlaget.

Mausethagen, S. (2015). Læeren i endring? Om nye forventninger til larerprofesjonen og læererarbeidet. Oslo: Universitetsforlaget.

Miles, M. B. \& Huberman, A. M. (1994). Qualitative Data Analysis. An Expanded Sourcebook. Thousand Oaks, California: Sage.

Molander, A. \& Smeby, J.-C. (2013). Innledning. I A. Molander \& J.-C. Smeby (red.), Profesjonsstudier 2 (s. 9-16). Oslo: Universitetsforlaget.

Molander, A. \& Terum, L. I. (2008). Profesjonsstudier: en introduksjon. I A. Molander \& L. I. Terum (red.) Profesjonsstudier (s. 13-27). Oslo: Universitetsforlaget.

Muller, J. (2009). Forms of knowledge and curriculumn coherence. Journal of Education and Work, 22(3), 205-226.

Munthe, E. \& Rogne, M. (2015). Research based teacher education. Teaching and teacher education, 46(2), 17-24.

Skagen, K. (red.) (2006). Lcreruddannelsen i Norden. København, Lund, Kristiansand: Unge Pædagoger, HLS, Høyskoleforlaget.

Smeby, J.-C. \& Heggen, K. (2014). Coherence and the development of professional knowledge and skills. Journal of Education and Work, 27(1), 71-91.

Thagaard, T. (2006). Systematikk og innlevelse: en innføring i kvalitativ metode (2. opplag): Oslo: Fagbokforlaget.

Thornton, R. \& Nardi, P. M. (1975). The Dynamics of Role Acquistion. American Journal of Sociology, 80(4), 870-885.

UiT (2013a). Studieplan for integrert mastergradsprogram i lcererutdanning 1.-7. trinn. Tromsø: UiT Norges arktiske universitet.

UiT (2013b). Studieplan for integrert mastergradsprogram i læererutdanning 5.-10. trinn. Tromsø: UiT Norges arktiske universitet.

Zeichner, K. (2010). Rethinking the Connections between Campus Courses and Field Experiences in College- and University-Based Teacher Education. Journal of Teacher Education, 61(1-2), 89-99. 